\title{
Chromodomain-Helicase-DNA-Binding Protein 5
}

National Cancer Institute

\section{Source}

National Cancer Institute. Chromodomain-Helicase-DNA-Binding Protein 5. NCI

Thesaurus. Code C68559.

Chromodomain-helicase-DNA-binding protein 5 (1954 aa, 223 kDa) is encoded by the human CHD5 gene. This protein may play a role in neural system development and in neural tumor pathogenesis. 